\title{
"The disadvantages of a defective education": identity, experiment and persuasion in the natural history of the salmon and parr controversy, c. 1825-1850
}

\author{
Reuben Message \\ School of Geography and the Environment, University of Oxford, Oxford, UK \\ Email: reuben.message@ouce.ox.ac.uk
}

\begin{abstract}
Argument
During the second quarter of the nineteenth century, an argument raged about the identity of a small freshwater fish: was the parr a distinct species, or merely the young of the salmon? This "Parr Controversy" concerned both fishermen and ichthyologists. A central protagonist in the controversy was a man of ambiguous social and scientific status: a gamekeeper from Scotland named John Shaw. This paper examines Shaw's heterogeneous practices and the reception of his claims by naturalists as he struggled to find a footing on the "gradient of attributed competence" (Rudwick 1985). The case demonstrates the context-specific nature of expert-lay boundaries and identities and explores a range of material and linguistic resources available for negotiating them. Arguing for a view of Shaw's trajectory as simultaneously one of being a "practical man" and of becoming a naturalist, the paper explores both the permeability of social hierarchies in knowledge production and their effective role in the regulation of competency.
\end{abstract}

Keywords: natural history; controversy; status; identity; persuasion; species; ichthyology

Sociological analyses of inductive knowledge have inquired into the nature of the qualifications for participation in the socio-ethical communities that make up empirical science (McMullin 1992; cf. Shapin 1994). Indeed, the process of becoming a "ventriloquist for the object world" (Haraway 1997, 24) always involves the exclusion of ineligible identities, and judgments about when such discriminations are warranted on the basis of actual and attributed competence (e.g. Collins 2014). Analyses of these processed are strongly associated with struggles for recognition within specific fields and are closely tied to perceptions of social status within salient scientific networks. Such struggles punctuate the history of natural history (e.g. Cain 2011), and they are especially noteworthy during periods of change in the practices, group composition, and associational structures of natural history, such as during the second quarter of the nineteenth century (Allen 1976, 1996; Porter 1978). In times of social change, unambiguous signs of belonging to the class of gentleman scholars were valued as their social institutions and mores underpinned many of the functional and epistemic practices of natural history (Rudwick 1985; A. Second 1994). Ambiguity of rank or background necessitated careful management of social exchanges in the scientific process, and great emphasis was placed on "character" and "connections" as a basis for the attribution of trustworthiness and scientific status (A. Second 1994, 389).

This paper examines the case of a Scottish gamekeeper named John Shaw and his relationship with established naturalists interested in the ichthyology of the British Salmonidae. In the mid-1830s, as the naturalist and illustrator of fish Sarah Lee wrote, the study of the genus Salmo in particular appeared to be in a state of great "uncertainty and confusion" (Lee to Jardine, 27 September 1837, in ANMS). Entering sharply into what was in fact a whole field of closely

\footnotetext{
(C) The Author(s) 2019. This is an Open Access article, distributed under the terms of the Creative Commons Attribution licence (http:// creativecommons.org/licenses/by/4.0/), which permits unrestricted re-use, distribution, and reproduction in any medium, provided the original work is properly cited.
} 
allied disputes, Shaw made fundamental contributions to the natural history of the salmon, and, in particular, to what became known as "The Parr Controversy." This debate reached its zenith throughout Britain, but in especially the Scottish borders region, during this time. It had as its core the question of whether a particular fish - commonly called "parr" and known to naturalists as the Salmo salmulus - really existed as a distinct species, or whether it was merely the juvenile form of the Salmo salar (Atlantic salmon) or another species of non-migratory trout?

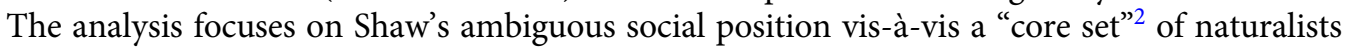
(Collins 1981). Responding to their criticisms of his arguments, Shaw claimed that he suffered under the "disadvantages of a defective education" (Shaw 1838, 165). Indeed, he was described as a "practical man": he was largely unsocialized in the community of experts, and he lacked relevant educational credentials. However, he had other advantages, including a profession and location that gave him unparalleled access to, and practical knowledge of, the rivers and their fish. Importantly, as well as being a "practical man," he was also a scientific novice who worked hard to get to grips with the demands of scientific discourse, to demonstrate his competence, and thence be recognized by scientific society - something he was ultimately successful at doing. ${ }^{3}$ From this perspective, the paper views Shaw's assault on the received opinions of the naturalists in terms of his grappling to improve his scientific status or position on what Martin Rudwick called (in the context of his study of geological controversy during this period) a "gradient of attributed competence" (Rudwick 1985, 419). In doing so, the paper will examine the dynamics and key "technologies" - social, literary, material, and experimental (Shapin 1984) - that were deployed and mediated Shaw's evolving relationships.

Shaw alleged an opinion that went against what was held to be true by most of the small cadre of ichthyological elites whose views on the Salmo counted most: namely, that salmon do not migrate to the sea the same spring that they hatch from their eggs; that the Salmo salmulus did not exist; and that "parr" were merely young salmon. Moreover, he adopted an experimental strategy - the artificial breeding and rearing of salmon as a means to study their early life history and species relations. Not only was this approach technically innovative in this context, but it also helped to circumvent reliance on the privileged and esoteric skills of morphological discrimination which the naturalist-qua-taxonomist takes as their special province, and which Shaw's ambiguous status suggested he may not be competent to possess. While his experimental contributions were to some extent first judged according to pre-existing views of the reality of the phenomena in question and his methodology accordingly critiqued, it was eventually through his control of empirical-experimental discourse - including improvements in experimental system, presentation of evidence, and the use of rhetoric attuned to the social context of the controversy together - that Shaw eventually found favor and foothold on the slope of scientific status. The parr controversy thus offers a case study of factors shaping the negotiations over scientific authority and competence in a neglected branch of natural history during a key period and specific locale. Additionally, the paper will suggest that relational processes of status "attribution" do not imply that substantive expertise plays no role in authority-construction (see Collins and Evans 2007). Moreover, the collective processes and arrangements in which "attribution" occurs may also work to maintain the functional exclusiveness and hierarchical order that defines the typically high-levels of cognitive co-ordination and norm conformance that characterizes specialist knowledge production in the natural sciences (see Barnes 2007).

\footnotetext{
${ }^{1}$ Previous discussions of the parr controversy are few, it having only been mentioned briefly in the context of the history of fish breeding (Coates 2006, 41; Wilkins 1989, 24-25), or in the context of biographical treatments of British naturalists' Jardine and Selby (Jackson 1992; Jackson and Davis 2001).

${ }^{2}$ On the applicability of the theory of the "core set" concept to natural history controversies at this time, see Rudwick (1985), 426. Collins' "core set" theory argued that a relatively small group of scientists tend to engage in controversies, and their judgments on the topic set the terms for the scientific community as a whole.

${ }^{3}$ I would like to thank an anonymous reviewer for suggesting emphasizing the importance of this two-sided aspect of John Shaw's relationship to the scientific establishment.
} 


\section{Ichthyology and the "dignity of natural history"}

Changes in the social organization of science, including natural history, during the first half of the nineteenth century included social differentiation, professionalization, and specialization. Such processes involve many forms of "boundary work" (Gieryn 1983). The 1830s, a time of social change in Britain more widely, are especially notable for these tendencies. In 1834 William Whewell noted a movement towards "an increasing proclivity of separation and dismemberment" (quoted in Ross 1962, 71). One aspect of this was the proliferation of sub-disciplines, and their embodiment in ever more specialist societies. At the same time - and of special consequence in natural history - there existed a special variant of this wide field of "demarcation disputes" connected to the continuously emerging distinction between "authentic" scientists' representations of the natural world and those of "the general laity" (Shapin 1982, 172). While natural history has often been thought of as the "bucolic science," it is said that this is an image of it often created by its popularizers: the word "amateur" in fact increasingly came to mean "dilettante" rather than "connoisseur," and its integrity came to be subject to intense policing (Drouin and VincentBensaude 1999, 410-11, 417-418). Rudwick's notion of a "gradient of attributed competence" suggests that these boundaries could be blurry and negotiable - but they also had real force.

Connected closely by geography and social and economic ties with the Border's region, Edinburgh scientific society became the main though not exclusive seat of the parr controversy. Interestingly, it may have bucked certain of these trends to some extent. At mid-century, prominent members of its most prestigious institution, the Royal Society of Edinburgh (hereafter RSE), still urged that the society "ought not exclude the dilettante and the amateur," and it could not sustain the appetite for specialist societies in the same way London could (Shapin 1974, 100, 112-114). Still, naturalists connected to the study of British fishes were concerned about the difficulties posed by the involvement of laypersons and non-specialists. This applied, perhaps more rarely, even to those of high scientific status in other fields. For instance, some doubted the credibility of the famous chemist Sir Humphry Davy on the topic of zoology, he having recently published a book on angling in which a theory of the parr's origins was aired (Hamilton 1843, 124; also Jenkins 1840, 163; see Davy [1828] 1832). ${ }^{4}$ Discussing a proposed publishing venture - a Journal of Zoology and Botany - Leonard Jenyns warned Sir William Jardine (a central node in the network of naturalists engaged in the study of parr and salmon) of the need to "uphold the dignity of the two sciences" and worried that "too much has been sacrificed to popularity of late years" (Jenyns to Jardine, 5 February 1836, in ANMS). Indeed, ichthyological literature at the time expressed an ambivalent attitude towards popular knowledge, whilst tending at the same time to be influenced by it and, perhaps as consequence, suspicious of "Billingsgate naturalists." The Edinburgh anatomist and commentator on the parr controversy Robert Knox showed his elitism when he apologised to his readers for having delved into questions of "trade or the usual business of life": although his study of salmon development, he claimed "in its essential nature is strictly anatomical and physiological, and can be investigated with advantage only by the anatomist and physiologist," he said he found it "unavoidable" that the "practical details" would become connected to "the scientific part." But he argued vociferously against the possibility of an "amateur angler or fishmonger" being credible contributors to the natural history of fishes (Knox 1833, 462, 464).

Reasons why such "mixing" was "unavoidable" were pragmatic and methodological. Letters sent by naturalists involved in the parr controversy, like Richard Parnell and William Yarrell, for example, reveal how they relied on fishermen and fish sellers for specimens and information about their habits - sometimes to their great frustration (e.g. Parnell to Jardine, 14 June 1836b, in ANMS; Yarrell to Jardine, 9 September 1835b, in ANMS; Yarrell to Jardine, 1836, in CULA). Indeed, scientists have often relied on fisherman and anglers for specimens and "local knowledge," and sometimes been influenced by their views (see e.g. Schneider 2000); all field sciences have to

\footnotetext{
${ }^{4}$ Davy was another occasional visitor to Scott's house at Abbotsford, Melrose. He apparently urged the unusual thesis that parr were hybrids of no fixed kind (H. Davy 1832, 67-69).
} 
contend with problems connected to social heterogeneity in ways that the more insulated laboratory sciences do not (Kohler 2002).

While inevitable and sometimes valuable, these relations could also problematic, especially when exchange partners ventured to use their experience of the fisheries to advance knowledge and theory. Rudwick $(1985,424)$ argued that the contributions of the lower rungs in the scientific status ladder in geological debates of the 1830s and 40s were most easily accepted when they limited themselves to factual reporting, for instance, of local occurrences, and the same is true in ichthyological circles. Articulating one part of the problem, the manager of the Duke Sutherlandshire's fisheries argued in the Transactions of the Royal Society of Edinburgh that errors had been made in the identification of migratory Salmo due to the mistaken belief that the opinions of "practical" or "professional fishermen," because of their "more enlarged experience, were supposed to carry greater weight" (Young 1844, 343). And, writing of the Salmo, Yarrell recommended that "sportsmen" get better acquainted with zoology, because this would allow them to appreciate the external anatomical characteristics, such as the "number and situation of the teeth, the forms of the different parts of the gill-covers, and the size, form, and relative situation of the fins" that allow for more constant identification (Yarrell 1841, 2).

The Salmo presented special difficulties because of their plasticity and local variability, especially in their juvenile forms. One consequence of this was a profusion of vernacular names for them. In an amusing reflection of this, the salmon protection Act in England and Wales passed in 1862 defined "Young of Salmon" as any fish known by any of the following names: "Fry, Samlet, Smolt, Smelt, Skirling or Skarling, Par, Spawn, Pink, Last Spring, Hepper, Last Brood, Gravelling, Shed, Scad, Blue Fin, Black Tip, Fingerling, Brandling, Brondling, or by any other Name, local or otherwise." The list of names for adult forms of migratory Salmo was even longer. At a meeting of the British Association in Edinburgh in 1834, Louis Agassiz contended that "systematic authors" in Britain, "having allowed themselves to fall into error through the prevailing opinions circulated concerning the vast multitude of species of this genus, have been investigating the characters of a great number of merely imaginary species" (Agassiz 1835, 621).

This situation surely demanded that some expertise-based limitations be placed on who was authorized to create legitimate knowledge in this field. Of course, these forms of relative social permeability and heterogeneity in practical ichthyology at the time can be read as evidence of the relatively "democratic" character of the discipline, and it is certainly true that barriers to entry must have been lower than in many other areas of science. But an effect of this may nevertheless have been an appetite for preserving the "dignity" of natural historical disciplines, and in doing so, the status of those groups whose identity was connected to their distinct knowledge practices. The identification of species and arrangement of taxa being central to natural history and the self-image of natural historians, it is perhaps natural that they would see creating order in this muddled (socially and scientifically) situation as a means of gaining recognition or honor amongst themselves and beyond. Moreover, the competent exercise of the skills associated with identification of species are a privileged means of establishing reputation amongst naturalists (see Lorimer 2007, 923; also A. Second 1994). These skills, typically involving description of visible morphological traits, involve much tacit knowledge, learned over time and gained through experience and socialization in relevant communities, as well as relevant book learning (cf. Lynch and Law 1988). Clearly, trust in the competency of others is required to believe in their testimonies about such subtle matters as the changeable hues of a pectoral fin or relative appearance of delicacy in the shape of a fish's head. But even higher levels of trust are required when the plain reporting of facts is displaced in favor of more fundamental contributions to higher matters - such as the existence or not of a species identified by experts. In such situations, clear signals about social status are important as these will be read as proxies for inner quality (see Podolny and Lynn 2011, esp. 545, 547-551). "Inner quality" in this sense includes moral worth or

${ }^{5}$ The focus on status signalling in the context of sociological of science come largely from Robert Merton (e.g. Merton 1968). 
trustworthiness, but also technical quality or competence, the two being highly intertwined or reciprocal. Status signals can thus act as indicators of trustworthiness and those deeply socialized and interaction-based expertise's that are said to be essential in science (H. Collins 2001; Collins and Evans 2007). Following on from this, the following section introduces the present controversy in more detail whilst showing how Shaw was situated in the interstices of different social networks in a way that made his status ambiguous vis-à-vis the core group of naturalists engaged in debates about the natural history of the Salmonidae.

\section{Anglers and naturalists}

The orthodox view and nomenclature for Salmo salmulus or parr descended from the seventeenth-century authorities of Willughby and Ray (Willughby and Ray, 1686); it was recognized by Pennant (1769), and by leading authorities including Cuvier (see Lee 1828). ${ }^{6}$ This view persisted into the mid-1830s amongst most of those who studied the Salmonidae in Britain: as Leonard Jenyns put it, the parr was well "ascertained to be a distinct species" (Jenyns 1835, 427). While the view that parr were S. salmulus was based on a long tradition, it is notable for our case that this perspective had also been recently reasserted. In his first communication on the topic in 1834, Sir William Jardine, on the basis of a comparison of specimens of parr and common brown or river trout from the River Tweed, found himself confident in declaring the parr a distinct species (Jardine, 1834). His outlook was reconfirmed the same year during a trip to Sutherland in the north of Scotland, when he and his companions Wilson and Selby went on an anglingnatural history field trip during which they performed a dissection of a parr (see Jackson 1992, 107-15, 133; Jackson and Davis 2001, 58-59). The following year, Jardine (wrote again unequivocally that the fish ought to remain as the "Salmo salmulus of Ray" (Jardine 1835, 57). Wilson backed Jardine's opinion in an article prepared for the British Encyclopaedia, though appearing some years earlier as a pamphlet (Wilson 1838, 1842). These sentiments were also supported in print (as we will see in more detail later) by William Yarrell $(1835,1839 a, 1839 b, 1841)$, an important ichthyologist at the time, and avidly by Richard Parnell (1838; [1837] 1840).

But, as this brief precis of the status quo betrays, it should be clear that the issue was in fact unsettled. Amongst naturalists in this period who demurred from the orthodoxy was Dr Fleming $(1828,180)$, zoologist and geologist, who believed that parr were "generally agreed" to be either a young salmon or young sea trout, while Louis Agassiz (1835) conjectured that parr may be young common brown trout. The most heterodox theory at the time was that of Robert Knox. The notorious Edinburgh anatomist penned his own account, believing that the facts and problems the fish presented "not only upset existing theories, but show that the question of the parr is one involving the highest questions in animal physiology, and explicable, in all probability, only by an appeal to the laws regulating hybridism and transcendentalism in animal life" (Knox 1854a, 84). ${ }^{7}$ The fact that a diversity of perspectives on the issue existed amongst naturalists is significant, but to understand why the issue became pressing at this time we must look beyond debates amongst

\footnotetext{
${ }^{6}$ The standard synonymy for the species (not accepted) is given by Fishbase as Walbaum, J.J., 1792. (https://www.fishbase.de/ Nomenclature/SynonymSummary.php $\mathrm{ID}=121027 \& \mathrm{GSID}=51148 \&$ GenusName $=$ Salmo $\&$ SpeciesName $=$ salmulus $\&$ SpecCode $=$ 236\&SynonymsRef=13696).

${ }^{7}$ Knox was a skilled anatomist - for a time the most famous in Britain - and knowledgeable about British freshwater fishes. His relatively unusual arguments about the parr can probably be explained by his adherence to a strain of transmutationist theory based on a synthesis of Goethe's transcendentalist philosophical biology and Saint-Hillaire's transformationism, a postLamarckian proto-evolutionary theory (Richards 1989, 1994). The Salmonidae appear to have offered Knox an interesting study in this respect. This theoretical background differentiated Knox from the other naturalists discussed in this paper but so did the more colorful aspects of his professional life. Knox's public notoriety following his role in the Burke and Hare murder scandal facilitated the deterioration of his relationship with the academic cliques in Edinburgh from the mid-1830s, and he was struck from the Rolls of the Royal Society of Edinburgh in 1848.
} 
ichthyologists. This will help us to better establish the ambiguous social position John Shaw occupied when he entered the debate.

Indeed, in the 1820 s and 1830s, interest in this relatively minor ichthyological curiosity waxed amongst anglers in particular. Notably, there was at this time a growing belief that salmon populations were declining across Britain, with detrimental consequences for commercial salmon fishers and proprietors of salmon fishing, as well as to recreational anglers whose pastime was then beginning to boom in popularity (see Coates 2006; Osborne 2007; Robertson 1998). Searching for causes of the decline of salmon, some fell upon what was in their view a case of mistaken identity: parr may not be distinct fish after all, but rather juvenile salmon, and their unfettered capture by all and sundry might be damaging the stock. These pressures were especially felt in the Borders, a region of many rivers and streams in relatively close proximity to major population centers (Bertram 1858; Sheail 1998). This was also the area where the parr controversy waged most hot, with many participants in the debate, including Jardine and Shaw, either living in or near the district, or regularly renting fishing there. An anonymous source later in the century exaggerates but slightly in claiming that at this time "the par [sic] question had even ... become a burning one, all over the borders of Scotland" (A Scottish Ichthyologist 1881, 250).

There was nothing novel about the parr-salmon thesis per se. According to Knox $(1847,80)$, "the theory that parr were the young of the salmon had been common for at least 100 years" amongst villagers in places like Anndale in the Borders. But interest in this theory grew in proportion to the scale of problem it was perceived to be connected with. The sporting writer and artist William Scrope, forming an opinion on the subject around 1825, urged the matter upon a Member of Parliament who was at that time chairing a governmental Commission of Inquiry investigating the state of the salmon fisheries. Scrope argued that, despite the opinions of naturalists and much of the public to the contrary, parr were in fact "the young of the salmon," that their destruction was habitual amongst certain sections of society and that, therefore, the matter was of consequence to the prospects of salmon fishing and the national interest (the letter is reprinted in Scrope [1843] 1898). Soon after, the poet James Hogg (1832) - "the Ettrick shepherd" - an acquaintance of Scrope's, published a detailed account of his own theories and observations supporting this claim. The issue was also well-known to Sir Walter Scott (see Scott 1828), who was himself close to both Hogg and Scrope, the latter renting an estate near to Scott's place at Abbortsford near Melrose in the Borders, and the former, famously, a regular fishing, hunting and literary companion.

It is unlikely that the rekindled interest naturalists began to take in the matter in the early $1830 \mathrm{~s}$ was unconnected to these developments. Additionally, the already "uncertain and confused" state of knowledge of the genus Salmo may have appeared more in need of resolution given the incursions non-naturalists were making on the topic. Jardine himself owned fisheries on the River Annan, and he also rented waters on the Tweed at The Holmes, some miles downstream of Melrose. He would have been well aware of the economic dimension of the parr question, and indeed noted that the decline in value of the salmon fisheries (he cited the case of the "south of Scotland" in particular) was a question, "independent of its interest as a difficult and unsolved question in Natural History" that was "of no little importance to proprietors" (Jardine 1830, 361). In this paper, moreover, he declared his belief that the only outstanding question as regards the parr's identity was whether it was a distinct species or the young of the common trout, as Agassiz thought. Jardine felt he could countenance the latter theory, though he favored the former (Jardine 1835, 57). However, when the opinions of a "fisher" named James Kerse that parr were young trout were presented to the Berwickshire Naturalists Club, Jardine did not express like toleration (Jackson 1992, 130, 165 n.13). ${ }^{8}$ Most importantly, he had absolutely no truck with

\footnotetext{
${ }^{8}$ James Kerse and Jardine angled with one another occasionally, although whether they angled as friends or whether Kerse acted as ghillie or assistant (which is more likely) is unknown. Kerse was also a gamekeeper at the Bowhill estate - another property owned by the Duke of Buccleuch, John Shaw's employer. Kerse's opinions were noted in the Magazine of Zoology and Botany, which Jardine edited (see “Communication from James Kerse, Fisher, Bowhill” 1837, 503).
} 
the thesis that the parr was merely the young of the salmon, a thesis popular "amongst anglers," he wrote (Jardine 1834, 82). Indeed, this view was cleaved to by most authoritative naturalists working in the field up until the late 1830s, including all those within the network of collaborators and correspondents that gathered around Jardine, including his friends Yarrell, Wilson, Jenyns, Parnell, Prideaux John Selby, Robert Hamilton, amongst others.

This helps to establish some of the key social contours of the controversy into which our protagonist John Shaw stepped. Shaw was a gamekeeper, a "practical man," albeit on the estate of one of the largest landowners in Britain. There are unfortunately few records of his life. ${ }^{9}$ Stoddart recalls that his cottage was well-kept, and "overlooked the valley a short way beyond the ducal castle" (Stoddart 1868, 288). Of course, he had a clear interest in the preservation of salmon, as did his noble employer the Duke of Buccleuch who was a keen angler, known to be actively interested in preserving his salmon estate (Bertram 1858, 84, 98). ${ }^{10}$ Moreover, the Duke's father had been on good terms with James Hogg, having settled Hogg on a farm the family owned. It is speculative to suggest that Hogg and Shaw may have met, though Shaw was clearly aware of Hogg's writing, and began his experiments shortly before Hogg's death in 1835. But it is possible that the association between the names Buccleuch and Hogg may have colored early reactions to Shaw's experiments. ${ }^{11}$ It is also possible that a connection to the powerful Buccleuch may have facilitated Shaw's access to the organs of science in Edinburgh, which the Duke and his family had long patronized. Indeed, Shapin's (1974) analyses suggests that a reason for Edinburgh science's relatively open attitude towards those of non-scientific background, in contrast to London, was the extensive influence wielded by the lowland landed classes, including Buccleuch, who often represented a union of interests in "improving science" with natural historians in areas connected to agriculture, like geology, meteorology, and forestry. Walter Montagu Douglas Scott, the $5^{\text {th }}$ Duke of Buccleuch and Shaw's master, was himself a member of the RSE (elected 1833), President of Highland Agricultural Society (1831-35), and from 1833 President of the Society for the Encouragement of Useful Arts in Scotland.

Shaw, however, never mentions his employer or overtly attempts to derive any kind authority from this source in his writings. Similarly, there is little clear evidence, in the published criticisms of Shaw's work, that it was his station and interests in life that directly lead him to be suspected of lacking the kind of freedom of action upon which the credibility of gentlemanly scientists were staked (see Shapin 1994). Indeed, the practical experience in Shaw's line of work could be presented as a basis for contributing to the debate. It is hard to judge the social status of gamekeepers generally. Munsche (1981) however suggests that in England it had historically been very low, the gamekeeper being a rather shady figure mediating between the worlds of proprietor and poacher. However, this image had begun to improve as the role professionalized in response to the increasingly complexity of the job in the early nineteenth century, including management of land and stock for high-intensity hunting. Indeed, Shaw was apparently respected for his "knowledge and experience with regards to the habits and preservation of game" (M'Turk 1843, 643). Indeed, emphasizing how "sedulously devoted" he was to his theme, Shaw reminded his readers that the "whole of [his] life" had been "spent on the banks of streams" (Shaw 1836, 99). As we will see further below, Shaw's rhetoric also adopted the dual position of experienced professional and

\footnotetext{
${ }^{9}$ See "Obituary of John Shaw," Inverness Courier, March 21, 1867. He is buried at Penpont Churchyard, where his gravestone reads: "Sacred to the memory of John Shaw who died at Drumlanrig Parks 13 March 1867 aged 70 years." I thank Catherine Gibbs of the Dumfries and Galloway County Archives for this information.

${ }^{10}$ Sources later in the century claimed that Shaw's employer, Walter Francis Montagu-Douglas Scott, $5^{\text {th }}$ Duke of Buccleuch, was personally interested in the parr question, but this is unverified (A Scottish Ichthyologist 1881, 250).

${ }^{11}$ There is no evidence that Hogg and Shaw ever met in person, although Hogg and friends including Sir Walter Scott, a longstanding friend of the Buccleuch family were known to go fishing and hunting in the district of Drumlanrig, and Hogg's wife was from Dumfriesshire. I would like to thank Hogg scholars Valentina Bold and Gillian Hughes for their help on this point.
} 
inexperienced scientist as a kind criticism of his learned audience. Others' engaged in salmonrelated controversies at the time did similarly: "Much cannot be expected from a mere salmonfisher, qui devient barbouilleur de paper malgré lui, in whose hand an OAR would suit much better than a pen," wrote one Murdo Mackenzie (MacKenzie [1834] 1860, 3). The advantage of this strategy is that it could bolster the claim to be a humble observer of facts whilst emphasizing a contrast between this and the dangers of academic theorizing. Thus a basis of practical experience gained in the ordinary course of life could potentially be converted into scientific status. Still, with respect of his position vis-à-vis natural history circles, Shaw's social position nevertheless provided him with at best an ambiguous starting point for entering scientific debate.

Shaw's vocation clearly set him apart from key scientific interlocutors, such as country scholars of independent means like Jardine, or urban professionals like Yarrell. Illustrating his ambiguous and somewhat enigmatic standing, he was never a member of either the Wernerian Natural History Society or the RSE - and yet his papers were read before the latter and published in associated journals, all highly respected forums (see Shaw 1836, 1838, 1840a). ${ }^{12}$ Robert Jameson, editor of Edinburgh New Philosophical Journal, in which Shaw's first two papers were published, is believed to have "encourage[d] the airing of both sides of controversial issues" (J. Second 1991, 15). ${ }^{13}$ Indeed, Jameson as founder of the Wernerian Society and editor of its journal the Memoirs would likely also to have been involved in the publication of one the first responses to Shaw's work Richard Parnell's prize essay on the "Natural and Economical History of the Fishes, Marine, Fluviatile, and Lacustrine, of the River District of the Firth of Forth" (Parnell 1838). This attitude may have also helped Shaw gain access and some traction. Still, it is instructive to contrast Shaw's lack of formal institutional memberships and concomitant social recognition in the 1830s to the situation within Jardine's circle. Here, memberships of the established scientific societies abounded, including the RSE and the Royal Society of London and the Wernerian, as well as the Zoological, Linnaean, Ray Societies, all of which were widely shared, as was membership of the British Association. Of equal importance, as already mentioned, was the network correspondence, collaboration and sometimes friendship that existed between many in this circle and complimented shared membership of societies. When Shaw emerged on the scene he was not a part these formal or informal networks; he was at best peripheral to them (cf. Rudwick 1985, 419, on the importance of the "informal and tacit" qualifications that membership of natural historical societies brought in addition to the official recognition such memberships represented). Such incomplete integration into relevant scientific networks are likely to affect the clarity of signals of reliability.

Shaw was of course never judged as though he were simply a member of the worst category of uneducated laity incapable even of offering reliable testimony on matters of fact (cf. Hume [1748] 1924). However, his social status did negatively affect judgments of his competency in certain respects. An area of particular relevance is that of perceptual competence, in particular, because of its centrality to the fine observational skills necessary in the refined analyses of the morphologies of the Salmo and their young. Indeed, it is believed more generally that snobbish evaluations of the competence of people in "coarse" or "mechanic" vocations in the early modern period survived as latent cultural conceptions long into the nineteenth century (e.g. Carlyle 1829; see Shapin 1994, 75-78; Shapin 1991, 314; Shapin and Barnes 1976). In the following sections, we turn in more detail to how these issues of social position and scientific status framed the challenges facing Shaw as a "practical man" and "novice scientific," and how his experimental and linguistic strategies responded to them.

\footnotetext{
${ }^{12}$ Shaw's final paper on the early life history of the salmon was republished as a pamphlet, see Shaw (1840b).

${ }^{13}$ I would like to thank an anonymous reviewer for suggesting this reference, as well as that of M'Turk (1843) cited vida supra.
} 


\section{A lack of constant specific character}

John Shaw's fundamental contribution to the resolution of the parr controversy was his contribution to the tracing of life course of the young salmon. As he wrote, he believed that "attempts hitherto made to trace the early history of the latter fish have been unsatisfactory and fanciful" (Shaw 1838, 99). Using a new technique, he tried to show the continuity of its forms - the "parr form and the adult "salmon" - through sexual descent. By way of contrast, those who argued for the existence of the salmulus concentrated their energies on the enumeration of its supposedly distinctive morphological characteristics. Avoiding going head-to-head on this topic by engaging directly with the inconsistencies and problems encountered in trying to provide definitive species characteristics was astute on Shaw's part: it helped to avoid a direct confrontation with the fundamental problem of proving a negative (the non-existence of the species) and the practical difficulties consequent upon the extreme variability of the animal and its similarity in appearance to its congeners. Equally, given the importance of the skills requisite to perform this kind of observation to naturalist's identities, combined with Shaw's ambiguous status in the field and possible doubts about his competence in this regard, adopting a different tack was not only technically desirable but also socially necessary.

An exclusively morphological approach to the problem involved difficulties. According to Parnell, the fish apparently lacked a "constant specific character" (Parnell 1840, 154). The most obvious feature of the $S$. salmulus or parr was the series of distinct bands or blotches on their sides - the so-called "parr marks" (see fig. 1). These "dark finger-like markings upon their sides," said Wilson (1842 [1838], 208), had "naturally assisted" an erroneous conclusion that parr are either young trout (of one variety or another), or young salmon because these are a feature common to all of these fishes. Illustrating the problem here, Wilson $(1838,208)$ noted that in S. salmulus these bands were "narrower in form" than in either young salmon or trout Jardine but in 1843 (after John Shaw's experiments had been widely accepted), Hamilton (1843) used exactly the same description of the marks to support the contention that they are young salmon. Unsurprisingly, Jardine $(1834,82)$ wrote that "only a few persons at the present time" are capable of pointing out "the distinctions which separate [the parr] from its congeners." Seemingly, it was even possible for someone of Jardine's skill to make mistakes: searching for a suitable specimen of salmulus, Parnell complained to Jardine that the example the latter had sent to him had been misidentified by him (Parnell to Jardine, 17 January 1838, in ANMS). No doubt, the actual nature of the bodies of these fishes seemed to ceaselessly resist classification in terms of clearly discernible morphological traits, even to the expert eye.

While detailed descriptions of $S$. salmulus where offered by the likes of Parnell and Jardine, it had nevertheless long been the case that arguments against the fish's identity with salmon required additional support in the form of arguments about the fish's habits and ecology (e.g Pennant 1769, 254). For example, it was said that "true parr" were found in rivers where salmon were never known to occur - a "good logical argument" in favor of them being a distinct species, as Wilson put it $(1838,208)$. Additionally, and most importantly for understanding Shaw's claims, in the early 1830s it was also widely believed that salmon mated and laid their eggs in autumn and winter; these hatched in spring, and within a mere few weeks the young fish had grown into smolts - silvery fish, typically in the region of eight or nine inches in length, a developmental stage signifying their readiness to migrate to the ocean, a journey which commenced shortly thereafter (see e.g. Knox 1833). Since parr were generally agreed to be present in the rivers where they occurred all year around, this was interpreted as a reason for it being impossible that the two could be identical in species. Against this argument, it was possible to scrape off the silvery scales of smolt in order to reveal the distinctive parr marks that remained beneath them - as Scrope, for example, had done (see fig. 2). But, their being characteristic of all young Salmo and adult Salmo salmulus, this seemed to some to beg the question. As in the case of parr being present in rivers where salmon are not known to occur, the argument would remain inconclusive so long as the possibility of mistaken identity remained high. 


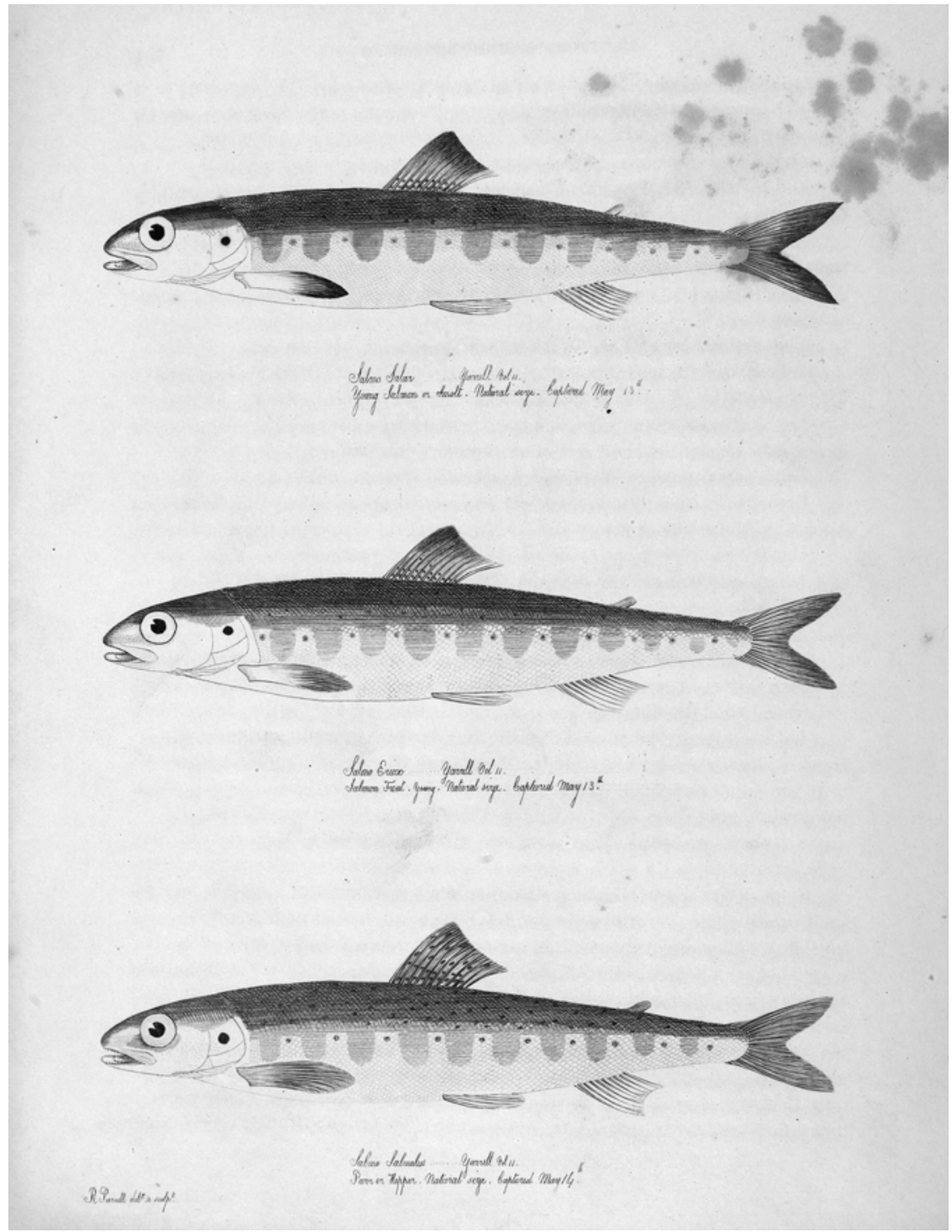

Figure 1 The illustration compares an S. salmulus (bottom) to a juvenile Salmo eriox (middle) and juvenile Salmo salar (top). S eriox (or "bull trout") are, like parr, no longer believed to constitute a distinct species. Notice the banded "parr marks" are depicted as common to the salmulus as an adult fish and to the young of the other species. From Parnell, R. [1837] 1840. Account of a New Species of British Bream, and of an Undescribed Species of Skate. Transactions of the Royal Society of Edinburgh, 14:146-157. Permission to reproduce courtesy of the University of Glasgow Library, Special Collections Department.

Finally, there was the problem of what came to be known to biologists as the "precocious parr," and connectedly, issues arising from the difficulty, as Wilson $(1838,208)$ conceded, that the mode of "its breeding ha[d] not yet been discovered." All participants in the parr debates acknowledged that small male fish of banded appearance, including those understood to be salmulus, were often found to be sexually mature: they contained milt or the "seminal liquor." Thus, the rhetorical defense arose: why would these fish be sexually mature, capable of contributing to the reproduction of its kind, if it were not in fact a species? Obviously enough, this argument implied the necessity of finding a sexually mature female counterpart. This became a holy grail of parr 


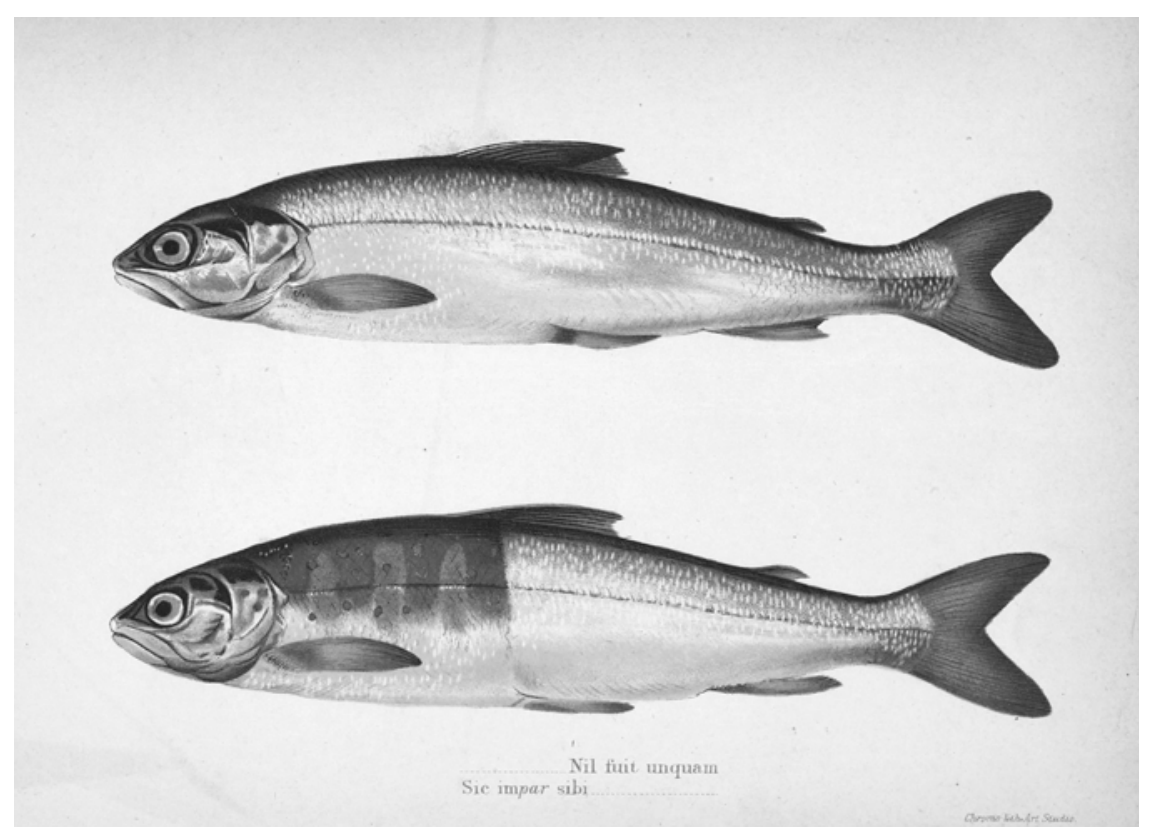

Figure 2 "Parr marks revealed underneath smolt scales." Scrope noted this phenomenon in the 1820s. Here, the illustrated specimen actually came from Shaw's ponds in 1842. William Scrope [1843] 1898. Days and Nights of Salmon Fishing, London: Edward Arnold, frontispiece. (c) The British Library Board, 7908.i.21/7.

science. A great deal of effort was put into finding a verified specimen - Parnell urged Jardine to keep any specimens that he chanced upon because they are "undoubtedly a rare occurrence" (Parnell to Jardine, 3 October 1836, in ANMS) - and much ink was spilt in disputing the claims of those who said they had found one.

Over the course of his experiments with salmon, Shaw's work grappled with these aspects in depth, especially the matter of the precocious parr and the rate at which young salmon matured. In particular, his demonstration that a large proportion of salmon fry do not migrate in their first summer but rather persist in the river as small banded fish for two years was of fundamental significance, so much so that it netted him the RSE's prestigious Keith Medal prize for 1840. Exactly what this meant for the matter of the existence or not of a distinct species of fish called parr commonly and Salmo salmulus scientifically, was however open to question.

Before describing Shaw's material and literary practices in more detail, it is instructive to ask: to what extent was his approach genuinely novel? Of course, the use of experimental methodologies in field studies in natural history were not new, though they may have taken on growing significance as the "field sciences" as such began to cohere alongside the emergence of the modern laboratory around the mid-nineteenth century (Kohler 2002). However, the application of a specific technology - artificial fecundation or breeding and incubation - as a part of a systematic effort addressing a specific problem - the natural history of the salmon and the species and varieties of Salmo - was innovative, if not completely original. Thomas Garnett, for instance, published findings not very dissimilar to Shaw's in 1834, and claimed to have performed artificial breeding sometime earlier (Garnett 1834). Apparently, a range of less celebrated practitioners were also experimenting with the idea of keeping young salmon in captivity in order to monitor their development prior to 1836: a Mr. Peat, "farmer to the Earl of Lonsdale's fisheries," for instance, is said to have dabbled in this matter in the hope of submitting his findings to the consideration of learned societies and "remedying the evil of the destruction of the spawn of fish" (Milton 1836, 64). 
It was Ludwig Jacobi, a German agriculturalist, who first reported the technique of artificial fecundation (insemination) of trout and salmon (see Orland 2017). Shaw apparently learnt about Jacobi's work via Humphry Davy's account of it in his angling treatise Salmonia (Davy [1828] 1832). ${ }^{14}$ In particular, Shaw seems to have taken from Davy the suggestion that Jacobi's technique could be applied not only as a means to increase the breed, but as a scientific tool: the "crossing the breeds of fishes." Davy wrote, "offers a very interesting and untouched field of investigation, which I hope will soon be taken by some enlightened country gentleman" (Davy 1832, $79-80$ ). Davy had in mind breeding different varieties of trout, or trout with salmon (and Jacobi had speculated on the possibility of breeding salmon and pike). Shaw however deployed the technology as a means of ensuring absolutely the parentage of a brood of fish, thus ruling out the possibility that the fish he claimed were young salmon were not actually young trout, hybrids, S. salmulus, or anything else.

This last point is very important because it connects to the criticism that Shaw, and "practical men" like him, were incompetent at discriminating the subtle differences between varieties and forms of Salmo. But it could not quite diffuse it - indeed, a range of other curatorial, witnessing, and rhetorical practices or technologies were required to allay the concerns of critics.

\section{The "sedulous devotions" of John Shaw}

Shaw's first paper records that he began his investigations on the $11^{\text {th }}$ of July 1833 by catching seven parrs from the River Nith and placing them in a secure pond in which he could observe their growth and development. On the $17^{\text {th }}$ May 1834, he caught them in a net, "and satisfied every individual present that they had assumed the perfect appearance of what is called the salmon-fry [smolt]" of about six inches long (Shaw 1836, 99). In March 1835, he caught more six-inch-long parr from the river, kept them in a pond, and found that by April they had assumed their migratory dress. On this basis he concluded "that there can be no room to doubt" that the large parrs found in autumn and following spring "are in reality salmon-fry," and that the "small or summer parrs" are those "of one year old, and that they must remain another year, before they depart in the character of salmon-fry" (ibid., 100). Thus Shaw began to construct his argument that there are always at least two generations of parr (young salmon) in the river at any time, and that a generation takes two years to ready itself for migration. This argument, it seemed to him, seriously undermined a central pillar in the argument that the parr was a distinct species. In support of the claim, Shaw, like others before him, also scraped off the silver livery of the smolt, revealing the parr marks beneath.

He needed to account for one "very extraordinary and perplexing circumstance," namely, that no signs of "this fish" could be found in rivers until the appearance of the small or summer parrs, from around May (ibid., 101). Shaw supplied this knowledge initially by meticulously examining the gravel beds (known as redds) on which salmon were known to mate during the winter. Hidden out of sight amongst the pebbles he discovered "a very small but active fish in vast numbers" (ibid.). These fish were then divided into two batches and kept in ponds and, Shaw says, they went through exactly the same stages of development as the fishes he'd caught and observed previously, and also reflected the changes that the fish he caught from river to compare them with were undergoing. Recognizing the weakness of his method - that he could not guarantee that the parents of these small fish found amongst the gravel were actually salmon, Shaw then began experimenting on salmon ova. This he did at first by observing salmon mating, and immediately scraping up their eggs in a gauze bag and removing these to a part of the stream bed convenient for observation. He watched the eggs develop, hatch, and the little fish - equipped with yolk sacs move down to hide in the gravel. By May 1836 these fish began to take on the characteristic banded appearance of parr.

\footnotetext{
${ }^{14}$ The New Bibliothetica Piscatoria (Westwood 1861) records Jacobi's work having been translated into English in 1778, and it was again in 1800 via the Transactions of the Dublin Society (see Jacobi 1800).
} 
At the same time, he began his first experiments with artificial fecundation. Initially, he does not seem to have given this aspect of his work great prominence, commenting only that it is "interesting as well from its novelty, as from its tendency to corroborate in part of the results of the former" (ibid., 106). In these experiments, Shaw caught two salmon and artificially fecundated them in the shallows of trench he'd cut in the side of the river. The fish he "held side by side, while with the hand I pressed the ova and seminal liquor out of their bodies, which mixed freely together in the stream" (ibid.). The fertilized eggs he placed in a side stream to incubate, and in due course they reproduced the same course of life observed in the parallel experiment.

Reactions to Shaw's account came quickly. Shortly after it appeared in July, Jenyns noted in a letter to Jardine that Shaw's "observations [were] contrary to all that has been previously entertained on the subject" (Jenyns to Jardine, 9 July 1836, in ANMS). Two criticisms of Shaw's work stand out. The first, as suggested by Shaw's decision to use artificial fecundation, was that his methods did not allow for certainty about the lineage of his broods. In his second paper, read before the RSE in December 1837, he moved to counter this problem by using a new rill separated from the main river, and performing the fecundation into an earthenware bowl rather than directly into the river gravel, where unseen ova or milt from other fishes might be hidden and spoil the experiment (Shaw 1838, 167-168). Later commentators like Charles Esdaile (pseudonym "A Rural D.D.") remarked that he resorted to this strategy only as a consequence of "being pressed to establish the fact that the spawn he had taken from the river, when producing the parr, was the spawn of salmon." Moreover, "[it]t was then only that he took to a plan that seems almost miracleworking; imitating by human agency the creative powers of nature and $\mathrm{Mr}$ Shaw resorted to it with little hope, but as a desperate endeavour to put [the] cavillers to silence" (A Rural D.D. 1853, 604). The second problem Shaw confronted was the accusation that the "strange, and perhaps unnatural, circumstances" (Couch 1865, 246) in which Shaw had placed eggs and fish may have materially altered their morphologies, growth rates, and habits. Doubting Shaw, Parnell $(1838,285)$ remarked that "all animals while placed under confinement, and deprived of their natural food" grow slowly and may be stunted. Yarrell raised similar issues, pointing specifically to the size of Shaw's ponds, the supply of food, and the differences in water temperature (Yarrell 1839b, 4). Shaw made strenuous efforts to allay these concerns: he performed his new experiments twice, using separate sources of water, and he was diligent at recording and reporting water temperatures, and comparing them to those of the River Nith nearby. "Every precaution," he wrote "has been used not only to exclude error, but to place the young fry in circumstances as nearly resembling the state of nature as was consistent with their preservation" (Shaw 1838, 166).

Parnell seems to suggest that the delicate variations of form and development of the fish may have been too subtle for the gamekeeper to have noticed. To support his criticism he referred to a story told by Yarrell about the slow growth of some trout confined in a well (Parnell 1838, 285). This is notable: it elevates a respected colleague's anecdote onto the same epistemic plain as Shaw's experiments, whilst doubting Shaw's experimental apparatus and the conditions in which his experiments were performed because they did not give the right results. Reminiscent of "experimenters regress" (Collins 1985), these conditions included a perception of Shaw's scientific status.

Shaw's papers are examples of socio-technical negotiation, at times more successfully so than others. Whereas in his first paper he had emphasized the unique opportunities he had in his occupation to observe the habits of salmon, he began his second communication with a slightly crabby rejoinder to his scientific critics, noting that the extreme difficult of studying salmon was a consequence of a number of social and technical factors. In particular, the "medium in which observations must necessarily be made, the migratory habits of the fish, and the proneness of scientific men to rear systems upon partial and insufficient data." While these all tend to "embarrass the question," "[t]hese difficulties alike best the path of the learned and the unlearned" (Shaw 1838, 165). But, he went on, "there is another difficulty which more particularly presses upon the latter, and that is, the scepticism with which his observations are generally regarded by scientific inquirers." Whether justified or not, it seems clear that he felt that the criticisms 
he'd experienced had been influenced by perceptions of his status. Suggesting at the same time that he was himself in the process of learning about the challenges of the discourse, the social rules that guide the cut and thrust of scientific debate, he then signals his loyalty to those rules: "This scepticism must obviously be met by increased industry and caution, and by an accumulation of evidence so conclusive as to overbalance the disadvantages of a defective education" (ibid.). Characterized by a great accumulation of detail, the repetition of experiments, and a number of refinements to his system, this second paper attempted to embody this spirit. And, at the same time as drawing attention to his compromised identity, Shaw displaces it by emphasizing evidence - and in doing so shows precisely those aspects of his character - his diligence, cautiousness, and respect for facts - that would likely encourage confidence in him amongst gentleman naturalists.

An example of Shaw's adaptation is the diligence he demonstrated at recording and reporting differences in water temperature in his system and the river. By openly recognizing that the colder temperatures associated with the spring water he was now using could retard growth rates, rather than hiding inconvenient observations, Shaw could better support his claim to be "careful practical observer, and honest inquirer after truth," and thus strengthen his argument that these differences would not have significantly affected the final result (Shaw 1838, 175). Shaw also returned to the mystery of the sexual maturity of the male parr. Here caution was required as Shaw risked moving away from "factual" reportage and towards, as he put it, offering a "speculative solution." This could have hurt his cause: as Rudwick $(1985,424)$ noted of amateur geologists, theorizing from a position of low scientific status might rouse suspicion as it did not express sufficient deference. However, Shaw managed to qualify his words, and noted that the phenomena was really "a difficulty not easily reconciled with the opinion I entertain as to its being the young of the salmon" (Shaw 1838, 175). By willingly drawing attention to issues that could hurt his case, Shaw could demonstrate his disinterestedness and build up his reputation. At the same time, he also developed a number of strategies for counterbalancing reliance on his word - "virtual witnesses," as Shapin (1984) called them. These included the narrative style and the accumulation of detail, which convey a sense of proximity and conscientiousness. Additionally, he kept the skins of the salmon he'd bred from for others to see, and he now supplied a number of fine drawings. These illustrated the layout of his ponds and their relation to the River Nith, emphasizing that although connected, it was impossible for fish from the wild to swim in and disturb the experiment, as well as a developmental series showing a salmon egg hatching and growing into a parr with its distinctive banded appearance. The former was reprinted in his next article, and the latter significantly improved in the form of a detailed coloured plate (see fig. 3).

Along with this third paper, the last dealing with the growth and development of the salmon, Shaw also significantly extended his curatorial practices by keeping and preserving specimens from his ponds at different stages of growth. He arranged to have these displayed when the paper was read before the RSE, along with comparative specimens of "salmon trout" (sea trout) spawned by artificial fecundation and the skins of their parent fishes, precisely because, he says "unscientific observers" have been accused being unable to tell them apart (Shaw 1840a, 557-558). His specimens were also inducted into the RSE's museum and displayed at the British Association meeting at Glasgow in 1840, thus affording scientific men the opportunity to view them at their leisure (see Wilson 1841 and 1843).

\section{"So powerful [the] operation of language and experiments"}

The trouble for Shaw however remained a serious one. However convincing he may have been about the developmental history of the salmon - and this was not a paltry ally - he could not conclusively prove that a distinct small fish, known as S. salmulus and commonly called parr, didn't exist out there in the rivers and streams of Scotland. Shaw might be admired for having shown something interesting about salmon, but the "additional proposition that the Parr does 


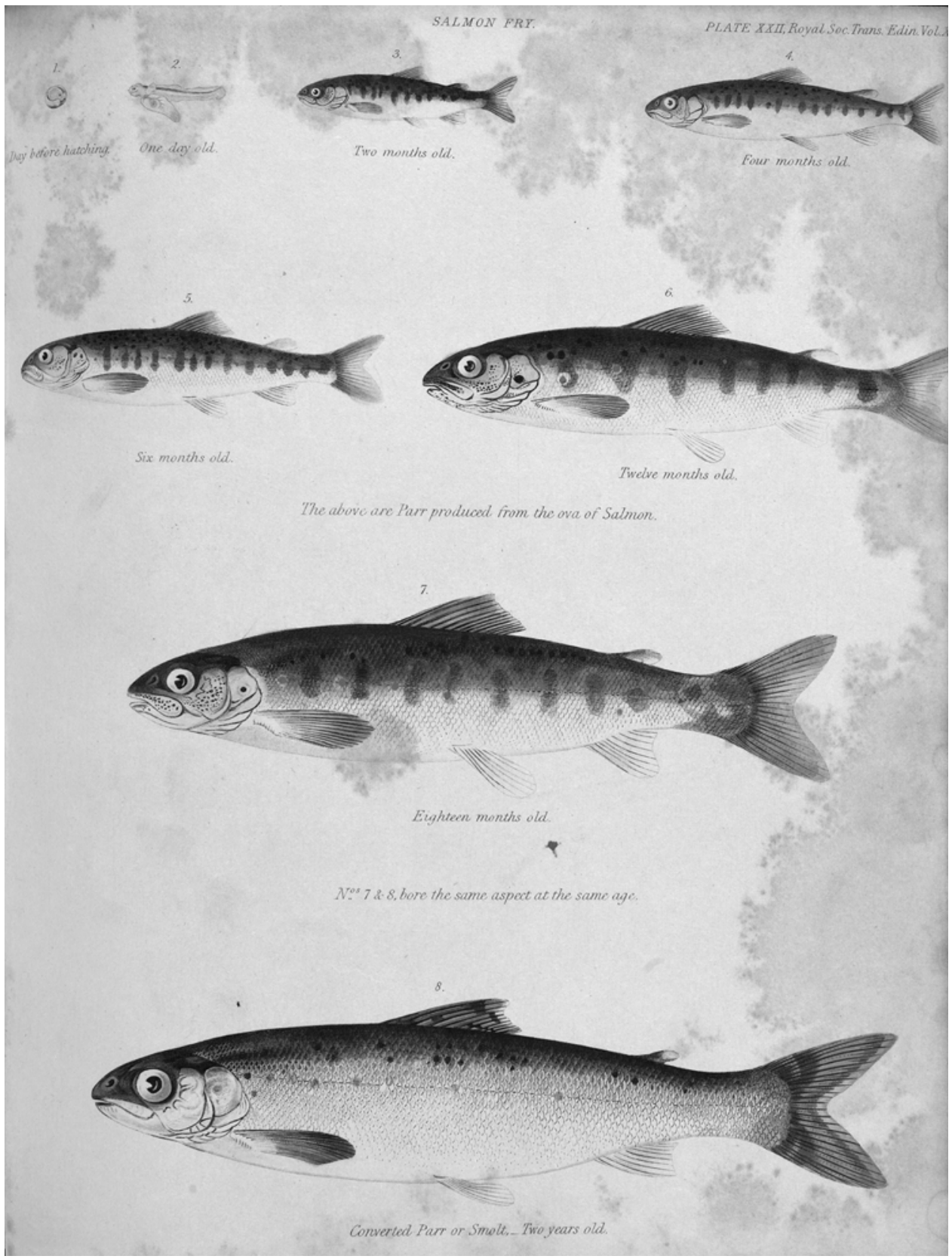

Figure 3 "Salmon fry": a developmental series. From Shaw, John. "Account of Experimental Observations on the Development and Growth of Salmon-Fry." Transactions of the Royal Society of Edinburgh 14, no. 2 (1840a): $547-66$. Permission to reproduce courtesy of the University of Glasgow Library, Special Collections Department.

not exist," as one reviewer put it, "is extremely questionable" ("Bibliographic Notices" 1840, 330). Decades later, a writer put the criticism Shaw received from naturalists on this score more colorfully: "'My good man,' said one of the learned, 'you have only proven what we all know, and have long known, that salmon produce salmon. You have simply collected the eggs of the salmon and they have in due time grown into like fish; any person could do that"' (A Scottish Ichthyologist 
1881, 139). Richard Parnell agreed that Shaw's experiments on the growth of salmon were "undoubtedly interesting" (Parnell to Jardine, 9 June 1837, in ANMS), and later admitted to Jardine that "I cannot argue with Shaw regarding the migration of the young salmon" (Parnell to Jardine, 5 January 1838, in ANMS). But he fervently rejected Shaw's conclusions on the identity of parr. Yarrell similarly reported being "willing to believe" Shaw that the young fish do not migrate until the second year of life "because he [Shaw] has devoted great attention to the subject," but he declined to support Shaw on the matter of the parrs' identity at this stage (Yarrell 1839a, 2).

Shaw seemed to come close to conceding. In a peevish statement, he suggested that "even if he has failed in convincing naturalists of the identity of the parr and the young salmon," he has surely contributed something of note from a "scientific or economic point view" (Shaw 1838, 174). While he stuck to his opinion about parr, the emphasis he placed upon his theory was reduced. While the title of his first paper, "An Account of some Experiments and Observations on the Parr, and on the Ova of the Salmon proving the Parr to be the young of the Salmon,", drew attention explicitly to the controversy about the parrs' identity, the titles of his second and third papers focused on the development and growth of salmon fry only. It was for his contribution to understanding the early life history of salmon that he was awarded the RSE's Keith Medal in 1840, not for "solving" the parr controversy. Surely anyone viewing what he had could not deny the connection between the two issues, and posterity remembers him thus, but this shift in the representation of the issue is significant as it minimizes the role of the "practical man" in settling an issue of species identification, and it would allow the necessary space for those most heavily invested in this core aspect of their speciality to concede with dignity.

If we examine in more detail the criticism Shaw received between 1836 and the publication of his third paper in 1840, and the wider recognition of his claims thereafter, we can even better appreciate the role played by social expectations of him. Yarrell criticized him for not having produced any "conclusive evidence of the non-existence of a distinct small fish," saying that experiments claiming to show to the contrary showed rather "the want of power among general observers to distinguish between the young of closely allied species" (Yarrell 1839a, 2; emphasis added). The emphasis placed on visual discrimination as the basis species identification work is clear. Parnell, the most vocal of Shaw's critics between 1837 and 1839, acknowledged the issue was one of extreme difficulty, but he objected repeatedly to "[p]ractical fishermen, [not] being acquainted with the characters by which the parr is distinguished" inveighing on the topic (Parnell 1838, 303). Moreover, others in similar positions to Shaw were similarly censured: Mr. Peat's claims on the topic were jeopardized by naturalists who doubted "the individual's knowledge of the characteristic and distinguishing marks of the fish he confined" (Milton 1836, 63). In a more extreme case, Knox rallied also against the contributions of such men and their experiments. He objected not only to the implications of the experiment for the issue of the identity of parr, but also to its validity with regards to the migration time of salmon (Knox 1854b, 45). Referring to the RSE's awarding of the Keith Medal as so much "clatter and uproar," he responded to the pride of "the Royal Society and to the mechanical matter-of-fact men," that another "mechanical man" will arise to "refute you," as indeed was the case when Andrew Young proposed a new migration time of one year (as opposed to Shaw's two), and never claimed that his experiments proved the non-existence of S. salmulus (see Young 1844, 1848). ${ }^{15}$ In this light, the view that the growth in popularity of experiments in this field "appear[s] to have had no further effect than an increase

\footnotetext{
${ }^{15}$ Notably, it had been Young who had provided Jardine's party on their tour of Sutherland in 1834 with specimens that apparently confirmed Jardine's opinions at the time, see Selby to Fox, 24 March 1835, UGSC; also see Jackson (1992), 133. Moreover, Young's contribution to the parr controversy is curious because his experiments were often in later years cited as corroborating Shaw's on the identity of parr. But closer reading of contemporary documents suggests Young himself equivocated. Ephemera (pseud. Edward Fitzgibbon, a well-known angling writer) collaborated with Young on chapter in which they argued that Shaw was wrong, and that it is clear that the fins of true parr "are little more than half the size of the [salmon] fry", and this was clear evidence that they are different kinds of fish (Ephemera 1850, 226).
} 
of the confusion that already existed" is not entirely unjustified (Couch 1865, 245). Knox insisted that he would retain his opinion until refuted by "qualified men" (Knox (1854b, 45).

Parnell's letters to Jardine provide the most interesting testimony however. "It is evident enough," wrote Parnell, "that he [Shaw] does not know the parr from the young of the salmon." If Shaw could only see the two correctly compared, "he would never maintain his opinion again" (Parnell to Jardine, 13 June 1836, in ANMS). Parnell was disappointed when Jardine did not speak up against Shaw when a paper of his (Parnell's) was read at the RSE, thus leaving the audience under the mistaken impression that both he (Parnell) and Jardine agreed with the gamekeeper (Parnell to Jardine, 9 June 1837, in ANMS). He worried that Shaw was already proving successful in "converting nearly the whole tribe of amateurs" (Parnell to Jardine, 5 January, 1838, in ANMS). A few days later, he wrote of a meeting at the RSE at which his views on parr were again discussed: "Many persons came from the Tweed to hear, as they declared, a true history of the habits of the parr." Three of these were tacksmen (fishers), invited there by "Dr K" [Knox]. One of these apparently explained to Parnell that their purpose was to "smash my observations." "I think," he explained with exasperation, that "when we have specimens before us which have puzzled naturalists to identify," it is intolerable that "practical fishermen can over turn matter of facts, for before we thought to argue on the habits of an animal we must first be able to discriminate it when having it before us" (Parnell to Jardine, 17 January 1838, in ANMS; emphasis in handwritten script). For Parnell, it seems almost as though a social breach here menaced the morality that underpinned epistemic order, and the best means of defending this was to emphasize the rare ability "to discriminate" between different specimens. Parnell also cited a hope previously communicated to him by Yarrell that, at an upcoming meeting of the British Association where the parr controversy was slated for discussion, "the naturalists will this time muster strong" (Parnell to Jardine, 13 August 1838, in ANMS). As we saw previously with the likes of Jenyns, Parnell appears to have been motivated to protect the dignity of natural history, and specifically scholarly ichthyology. Doing this by emphasizing a method, morphological discrimination, also had socially discriminatory consequences.

Shaw's third and perhaps most important paper was read at RSE on the $16^{\text {th }}$ of December 1839 , and later published in the Transactions of the Royal Society of Edinburgh, communicated by Wilson. It recapitulated the arguments of the previous two - but also added a series of new experiments targeted at making the problem of the precocious parr into an ally. In the most notable of these, Shaw described how he'd produced a precocious parr by breeding two salmon using artificial fecundation. This parr he then successfully bred with an adult female salmon, and, in time, the issue of this mating were in turn shown to be capable of reproducing their species - salmon. Shaw thus argued that, by a "law in the economy of nature" - that like produces like and that hybrids are infertile - he had proved "the parr and the salmon are really identical in species" (Shaw 1840a, 564). How influential this line of argument was is hard to judge in isolation of the assemblage of other elements, including the illustrative plates and specimens Shaw had now supplied - but it is a striking approach to the problem, and clearly suggests a departure from the kind of argument based on comparative morphological appearance favored by the likes of Parnell and others. The focus on relatedness by sexual descent may also reflect a wider movement away from what Foucault $(2002,139)$ called the static "grid" of traditional natural history.

Complimenting his material innovations, Shaw's rhetorical flourishes were calculated. In this last paper on the parr, he cited as an epigraph a quote from Herschel's Discourse on the Study of Natural Philosophy in which is noted that "experience" is the "fountain of all knowledge," and the reader is exhorted to "dismiss as idle prejudice, or at least suspend as premature, any preconceived notions of what might or ought to be the order of nature in any proposed case, and content ourselves with observing, as a plain matter of fact, what is" (quoted in Shaw 1840a, 547). He appears here and elsewhere to remind his scientific critics of their professed creed as empiricists. Parnell, for example, had written that the "great confusion" of the parr controversy would never be cleared up by "mere conjecture or hypotheses, but [only] by slow accumulation of facts, and the unsparing 
correction of error" (Parnell 1840, 155). At same time, however, such efforts can be read as evidence of Shaw novice status and as a part of an effort to show that he can master the rigors of empirical discourse, the culture of his interlocutors, and that he is no usurper. Indeed, it's hard to judge whether it's a brave rejoinder, or slightly cack-handed, though Shaw does seem to have learnt some subtlety. In 1836, Shaw was a little cavalier in his accusations. While he knew he was alleging against "the opinion held by most writers on the subject," he was unabashed and went so far as to state that opinions of such writers were "unsatisfactory and fanciful" (Shaw 1836, 99). It is not surprising then that they cavilled. By 1838, moderating his language, Shaw illustrated a better understanding of the rules of the game: since he had "no pretensions of scientific attainment," he claimed, he was "entitled to the indulgence of scientific men" (Shaw 1838, 175). Here, by claiming the inferior status position, he suggests that there is no honor to be won by abusing an inferior, demonstrating an instrumental awareness of how to work the honor-status system that regulated gentlemanly exchange in its connection to empirical discourse. ${ }^{16}$ In late 1839 , when his paper was read at the RSE, he noted that in addressing this "body of scientific men," he did not wish to see new errors substituted for old, and that in fact he considered it proper that they should have been slow to agree with him because his view ran contrary to the "received opinion both of scientific and practical observers." He then says that he believes that experiments such as his have previously been made "by no other individual on the same principle for a similar purpose; for had they been so, I am persuaded the real history and economy of this valuable and interesting fish would long ere now have been made more correctly understood by the community." But he makes up for the immodesty by urging if other experiments are made that contradict him, "the scientific public should be immediately apprised of them" (Shaw 1840a, 556).

Popular writers in later years, reflecting on the affray, certainly felt that the whole affair smacked of elitism. Esdaile described the attitude of a prominent journal as expressing "no nobler feelings towards him than to sneer at 'the practical man"' (A Rural D.D. 1853, 622); another wrote of the collective action of the ichthyologic establishment: no sooner had the "head-keeper to the Duke of Buccleuch" appeared when "almost instantly the whole tribe turned on him as a common enemy" (Russel 1864, 38). While not without some merit, these populist accounts are also certainly exaggerations. "The establishment," so to speak, rightly took him quite seriously, even as they were at first shocked by his claims. Jardine first heard of Shaw's experiments via John Bushnam, a local surgeon (Bushnan to Jardine, 3 February 1836 and 9 February 1836, in CULA). It's hard to say what kind of weight such a recommendation carried. But with Shaw and Jardine both being based in Dumfriesshire, it is quite likely that Jardine had already visited Shaw's ponds as early as 1837 (Jardine invited Parnell to visit Shaw with him at this time, although it is not clear if Parnell came along (see Parnell to Jardine, 5 January 1837, in ANMS). Indeed, the tide may have begun to turn in Shaw's favor prior to his third paper being read. The British Association charged a group of members, including Jardine, Selby, and Parnell, to investigate Shaw's work in 1838. And opinions of key members of the core network began to shift from around the time this time. Yarrell expressed conciliatory remarks, delayed publication of the second edition of his opus British Fishes in anticipation of Shaw's final communication, and Shaw sent him "two long letters" in 1839 (Yarrell 1841, 2:83-84; Yarrell to Jardine, 18 August 1839, in ANMS; see Jackson and Davis 2001, 63-64). Jardine seems to have been supportive of him by the time the second part of his British Salmonidae appeared in 1841 (Jardine 1839-1841). By this time, Jardine had not only visited Shaw at Drumlanrig, but had made preparations for some corroboratory experiments of his own at Jardine Hall on the Annan. ${ }^{17}$ Shaw and he also began a correspondence,

\footnotetext{
${ }^{16}$ For conceptual elaboration of the role of status dynamics in "agonistic" games in honor cultures, see Demetriou (2014). See also Anne Second (1994, 398-404) on obligation and deference relations in natural history correspondence.

${ }^{17}$ Little detail about these is available, but it seems they were less in-depth than Shaw's, and to have mostly involved the capturing and rearing of parr rather than breeding salmon and incubating and hatching their eggs, see J.H. (1876); also Jackson (1992, 133); Jackson and Davis (2001, 64-65). At best these experiments could have corroborated only parts of Shaw's program.
} 
the surviving letters of which show Shaw to be both helpful and deferential. For example, Shaw facilitated access to various ichthyological and ornithological specimens, while Jardine used specimens of sea-trout bred by Shaw as models for his illustrations, and when Shaw offered opinions on the species of a particular kind of buzzard, he was tentative and clearly mindful of Jardine's authority (see especially Shaw to Jardine, 18 May 1840 and 23 May 1840, in ANMS). As Anne Second's (1994) analysis of correspondence between artisan and gentleman naturalists shows, the control of rhetoric, and the opportunity to display good character offered via letter writing could be a means to enhance a writers' status, whilst mere participation in such correspondence signified to others participation in the community.

Thus, while the ensemble of material and curatorial strategies employed by Shaw contributed to the detente, his language also played a distinct role. Couch, an ichthyologist from Cornwall, spoke with a forked tongue, when he admitted that Shaw's "language and experiments" had together had great influence on "the minds of some eminent naturalists" (Couch 1865, 4:247). He never accepted that Shaw's work proved the non-existence of S. salmulus. But Couch was far away from the center of action, and it is believed that he possessed a firmer grasp of his local marine fishes than he did of their freshwater counterparts (see Wheeler 2004). On the other hand, Wilson, a man more proximate to the action, felt Shaw's language proved him a man of "sagacious and observant disposition" (Wilson 1840, 531). Shaw, moreover, "studiously eschewed books" in favor of spending time "upon the river bank with his eyes open." Indeed, in a humorous mea culpa, Wilson lampooned the "'men wot write'," comparing them to a herd of sheep (alas, "their habits rather those of fleecing than of being fleeced"). On the matter of salmon fry or parr, he declared, the "opinions" of learned commentators had now given way utterly to the "facts" of John Shaw (Wilson 1840, 537; emphasis in original). With such endorsements, and the Keith Medal to his name, Shaw had clearly gained a footing higher up on the "gradient of attributed credibility." While Shaw never became a Fellow of the high-status RSE, his new rank is perhaps reflected in his becoming an Ordinary Member of the local Dumfriesshire \& Galloway Natural History and Antiquarian Society in 1863, of which Jardine was President (see "List of Members" 1866, 12).

Next to Couch, Knox was perhaps the only recognised zoologist contributing to this field who continued publicly to demur from Shaw's conclusions. But by the time he made his most disparaging remarks in the early 1850s he'd been disgraced in Edinburgh circles and was penning his criticisms mainly in popular titles like The Illustrated London Magazine, or including them in his book about angling in Scotland (see Knox 1854a). Knox had, perhaps, slid down the gradient that measured scientific status in this field, and like Couch was now marginal to the geographical and social centres of debate on the matter. Parnell retained the respect of Jardine, but did not contribute on the topic again, and soon left the country for an extended tour of Jamaica (see Jackson and Davis 2001, 65). Reviewing the controversy in the 1850s, the surgeon John Davy asked rhetorically "what is the evidence that all parties would probably hold to be satisfactory or conclusive?" and concluded "[i]s it not showing that the parr, the asserted distinct species, propagates its kind, and that in due season, and at the same time, the male and female fish are to be found with roe and milt mature?" (J. Davy 1856, 253). This is precisely what people failed to do. Parnell in particular, despite his feverish collecting, had never been able to procure a female parr in the "forward state." In the absence of such a specimen, Shaw's provision of an alternative candidate was enough to shift the burden of proof onto those who wanted to claim that $S$. salmulus existed.

\section{Conclusion}

John Shaw's part in the parr controversy provides an illustration of how becoming a "ventriloquist for the object world" involved overcoming challenges associated with social qualification and position, as well as the technical difficulties of the subject matter. This involved the suspicions 
of incumbents about the presence of "practical men" of ambiguous social status in natural history, and efforts to master the challenges their discourse represented. The case suggests how this branch of natural history exhibited a tension between perspectives on the involvement of people like Shaw: it could be elitist and exclusive - but it was also far from the case that Shaw's voice was ignored. It is simplistic to read this story only as an example of a rustic or "practical man" contributing something significant to scientific knowledge, and in this was way affirming the capacities of a lay population to contribute to natural history more generally. That Shaw was ultimately successful in claiming a foothold on the "gradient of attributed competence" rather shows that the social processes this involved were in effect those of becoming a "scientific", or in other words, of changing identity within socially permitted parameters and using available resources. This involved the development and display of conformity in some respects, and a consolidation and improvement of methods and style of argument, to the extent that key members of the "core set" could accept Shaw's claims - despite their challenging nature and the ambiguous status of their source - without loss of face, precisely because his status was no longer as unclear as it had once been. He was an acceptable contributor who understood the importance of giving deference in order to receive it, who recognized the expertise of others, and who himself finally demonstrated true competencies in a specific area of some importance due to its connecting relevant questions in ichthyology and fisheries management.

It is possible to view the story of Shaw's success as evidence of the relative social openness of this branch of natural history during the period - and, in connection to this, the stance of Edinburgh science at the time more generally towards the involvement of laypersons. But it is another matter to infer on this basis that the distinction between the ways of knowing within specialist scientific communities and amongst the general laity is unfounded or easily breached, here or more generally. The argument, engrained in constructivist accounts of science and technology studies (Golinski 1998), that expertise, authority, status, or competence are (socially) attributed properties has however long lent its weight to exaggeratedly positive accounts of the capacities of lay people (see Kusch 2007). Concern about the "populist" implications of this emphasis on a "relational" to attribution has prompted a normative defense of expertise as "real and substantial" (Collins and Evans 2007, 2). But the account of the parr controversy in this paper illustrated the intertwining of both these points of view in practice. Importantly, it also suggests ways in which the sociological resources in question can be seen as building up or maintaining, rather than dissolving, hierarchical social distinctions relevant to producing reliable knowledge of nature. Collins and Evans (2007) focused on tacit knowledge embedded in interactions and socialisation into scientific communities as a warrant for genuine expertise. Another approach is to return, in Mertonian fashion, to examining how collective processes that maintain and regulate the division of scientific labour that supports epistemic integrity - as Barry Barnes did in his theoretical account of the "scientific status group" and their unique and highly exclusionary ways of distributing social honour in securing the high levels of norm conformance and cognitive co-ordination observed empirically in scientific communities (Barnes 2007). Insistence on credentials (including education) simultaneously invests the community with sinecure-like properties and ensures a degree of technical proficiency from those who would partake in the advantages of recognition the group bestows. ${ }^{18}$ Framing this paper with the device, drawn from Rudwick's (1985) contemporary account of geology of Shaw's struggles to gain a foothold on the "gradient of attributed competence" thus at first focuses our attention on forms of relational work

\footnotetext{
${ }^{18}$ This problem derives originally from Weberian sociologies of "social closure" and has been addressed in the context of educational credentials by Murphy (see 1988, 170; see also R. Collins 1979). Weber himself however may have erred in the opposite direction, writing that "normally this concern for efficient performance recedes behind the interest in limiting the supply of candidates for the benefices and honours of a given occupation" (Weber 1978, 344; quoted in Parkin 1979, 55). Weber's understanding of status and collective is however fundamental to both Merton and Barnes' accounts of regulation in science.
} 
that imply a blurring of the boundaries of the world and contributions of the "practical man" man and the "ichthyological elite". But looking at the story of Shaw and the parr controversy also as one of becoming a competent scientific and the collective regulation of status or identity therein thus also reveals a different and contrary quality.

Acknowledgments. The author would like to thank Carrie Friese for her help and encouragement, as well as the anonymous reviewers for their advice. The original research for this work was done with the support of a PhD Studentship from the London School of Economics, and was subsequently supported in part by the Wellcome Trust (Grant Number: 205393/A/16/Z).

\section{References}

\section{Archival Abbreviation}

Archives of the National Museum of Scotland - ANMS

Cambridge University Library Archives - CULA

University of Glasgow Special Collections - UGSC

\section{Unpublished Sources}

Bushnan, John. to William Jardine. 3 February 1836. Alfred Newton Papers, 'The Jardine Correspondence', MS Add. 9839/13/295, CULA.

Bushnan, John. to William Jardine. 9 February 1836. Alfred Newton Papers, 'The Jardine Correspondence', MS Add. 9839/13/295, CULA.

Jenyns, Leonard. to William Jardine. 5 February 1836. The Jardine Papers, GB 587 WJ, 2/56, ANMS.

Jenyns, Leonard. to William Jardine. 9 July 1836. The Jardine Papers, GB 587 WJ, 2/56, ANMS.

Parnell, Richard. to William Jardine. 14 June 1836. The Jardine Papers, GB 587 WJ, 4/101, ANMS.

Parnell, Richard. to William Jardine 3 October 1836. The Jardine Papers, GB 587 WJ, 4/101, ANMS.

Parnell, Richard. to William Jardine. 13 June 1836. The Jardine Papers, GB 587 WJ, 4/101, ANMS.

Parnell, Richard. to William Jardine. 9 June 1837. The Jardine Papers, GB 587 WJ, 4/101, ANMS.

Parnell, Richard. to William Jardine. 5 January 1838. The Jardine Papers, GB 587 WJ, 4/101, ANMS.

Parnell, Richard. to William Jardine. 17 January 1838. The Jardine Papers, GB 587 WJ, 4/101, ANMS.

Parnell, Richard. to William Jardine. 13 August 1838. The Jardine Papers, GB 587 WJ, 4/101, ANMS.

Parnell, Richard. to William Jardine. 5 January 1838. The Jardine Papers, GB 587 WJ, 4/101, ANMS.

Selby, John P. to George Fox. 24 March 1835. GB 2047/f68, UGSC.

Shaw John. to William Jardine. 18 May 1840. The Jardine Papers, GB 587 WJ, 5/118, ANMS.

Shaw John. to William Jardine. 23 May 1840. The Jardine Papers, GB 587 WJ, 5/118, ANMS.

Yarrell, William. to William Jardine. 9 September 1835. The Jardine Papers, GB 587 WJ, 6/145, ANMS.

Yarrell, William. to William Jardine, 18 August 1839. GB 587 WJ, 6/145, ANMS.

Yarrell, William. to William Jardine. 1836 [day and month unrecorded]. Alfred Newton Papers, 'The Jardine Correspondence', CULA.

\section{Published Sources}

A Rural D.D. [David Esdaile]. 1853. “The Salmon - Its Preservation and Increase.” The Journal of Agriculture, New Series (March):620-45.

A Scottish Ichthyologist (pseud.). 1881. “Trout Breeding in Scotland.” Baily's Magazine of Sports and Pastimes, 257(July):250-257.

Agassiz, Louis. 1835. "Remarks on the Different Species of the Genus Salmo Which Frequent the Various Rivers and Lakes of Europe." Report of the Fourth Meeting of the British Association for the Advancement of Science, 1834, 617-23. London: John Murray.

Allen, David E. 1976. The Naturalist in Britain: A Social History. Princeton: Princeton University Press.

Allen, David E. 1996. "The Struggle for Specialist Journals: Natural History in the British Periodicals Market in the First Half of the Nineteenth Century.” Archives of Natural History 23(1):107-23.

Barnes, Barry. 2007. "Catching up with Robert Merton: Scientific Collectives as Status Groups.” Journal of Classical Sociology 7(2):179-92.

Bertram, James G. 1858. The Border Angler. Edinburgh: John Menzies. 
"Bibliographic Notices." 1840. The Annals and Magazine of Natural History 4(25):329-34.

Lee, Sarah [neé Bowdich]. 1828. The Fresh-Water Fishes of Great Britain. London: Printed for the Authoress and R. Ackermann.

Cain, Victoria. 2011. "The Art of Authority: Exhibits, Exhibit-Makers, and the Contest for Scientific Status in the American Museum of Natural History, 1920-1940." Science in Context 24(2):215-38.

Carlyle, Thomas. 1829. "Signs of the Times." The Edinburgh Review 49(98):439-59.

Coates, Peter. 2006. Salmon. London: Reaktion Books.

Collins, Harry. 1981. "The Place of the 'Core-Set' in Modern Science: Social Contingency with Methodological Propriety in Science." History of Science 19(March):6-19.

Collins, Harry. 1985. Changing Order: Replication and Induction in Scientific Practice. London: Sage.

Collins, Harry. 2001. "What Is Tacit Knowledge?" In The Practice Turn in Contemporary Theory, edited by Theodore R Schatzki, Karin Knorr Cetina, and Eike von Savigny, 115-28. London: Routledge.

Collins, Harry, and Robert Evans. 2007. Rethinking Expertise. Chicago: Chicago University Press.

Collins, Harry. 2014. "Rejecting Knowledge Claims inside and outside Science." Social Studies of Science 5(44):722-735.

Collins, Randall. 1979. The Credential Society: An Historical Sociology of Education. New York: Academic Press.

"Communication from James Kerse, Fisher, Bowhill." 1837. Magazine of Zoology and Botany 1:503.

Couch, Jonathan. 1865. A History of the Fishes of the British Islands, 4 vols. London: Groombridge \& Sons.

Davy, Humphry. [1828] 1832. Salmonia: Or, Days of Fly Fishing, 3rd edition. London: John Murray.

Davy, John. 1856. "Some Miscellaneous Remarks on the Salmonidae." Transactions of the Royal Society of Edinburgh $7(2): 245-254$.

Demetriou, Dan. 2014. “What Should Realists Say About Honor Cultures?” Ethical Theory and Moral Practice 17(5):893-991.

Drouin, Jean-Marc, and Bernadette Vincent-Bensaude. 1999. "Nature for the People." In Cultures of Natural History, edited by Nicholas Jardine, James A Second, and Emma Spary, 408-25. Cambridge: Cambridge University Press.

Ephemera [Edward Fitzgibbon]. 1850. Book of the Salmon. London: Longmans, Green, \& Co.

Fleming, John. 1828. A History of British Animals. Edinburgh: Bell and Bradfute.

Foucault, Michel. 2002. The Order of Things. London: Routledge.

Garnett, Thomas. 1834. "Facts and Considerations on the Natural History and Political Impropriation of the Salmon Fish." The Magazine of Natural History 7(39):202-17.

Gieryn, Thomas F. 1983. "Boundary-Work and the Demarcation of Science from Non-Science." American Sociological Review 48(6):781-95.

Golinski, Jan. 1998. Making Natural Knowledge: Constructivism and the History of Science. Cambridge: Cambridge University Press.

Hamilton, Robert. 1843. British Fishes, 2 vols. Edinburgh: W.H. Lizars.

Haraway, Donna J. 1997. Modest_Witness@Second_Millennium. Female Man Meets Onco Mouse TM: Feminism and Technoscience. New York and London: Routledge.

Hogg, James. 1832. "On the Preservation of Salmon." Quarterly Journal of Agriculture 3(15):441-49.

Hume, David. [1748] 1924. An Enquiry Concerning Human Understanding and Selections from a Treatise of Human Nature. Chicago: The Open Court Publishing Company.

Jacobi, Ludwig. [1772] 1800. “A New Method of Breeding Trout and Salmon.” Transactions of the Dublin Society 1(2):119-132.

Jackson, Christine E. 1992. Prideaux John Selby: A Gentleman Naturalist. Stocksfield: Spreddon Press.

Jackson, Christine E., and Peter Davis. 2001. Sir William Jardine: A Life in Natural History. London: Leicester University Press.

Jardine, William, 1830. “Queries Respecting the Natural History of the Salmon, Sea-trout, Bull-trout, Herling, \&c.” Edinburgh Journal of Science 3(2):361-362.

Jardine, William. 1834. "Notice of the Parr." In History of the Berwickshire Naturalists' Club, 82-84. Edinburgh: Neill \& Company.

Jardine, William. 1835. "Observations upon the Salmonidae met with during an Excursion to the North-West of Sutherlandshire, in June 1834." The Edinburgh New Philosophical Journal 18(35):46-58.

Jardine, William. 1839, 1840. Illustrations of the British Salmonidae, published in two parts. Edinburgh.

J.H. 1876. "Obituary Notice of Sir William Jardine, Bart., of Applegirth.” Proceedings of the Berwickshire Naturalists' Club 7:402-6.

Jenkins, Thomas. 1840. “Observations on the Young of the Salmon.” The Magazine of Natural History 4(40):161-69.

Jenyns, Leonard. 1835. A Manual of British Vertebrate Animals. Cambridge: Pitt.

Knox, Robert. 1833. "Observations on the Natural History of the Salmon, Herring, and Vendace." Transactions of the Royal Society of Edinburgh 12(2):462-518.

Knox, Robert. 1847. "Recollections of the Researches into the Natural and Economic History of Certain Species of Clupeadae, Coregoni, and Salmonidae." In Report of the Sixteenth Meeting of the British Association of the Advancement of Science, 1846, 79-80. London: John Murray. 
Knox, Robert. 1854a. Fish and Fishing in the Lone Glens of Scotland, with a History of the Propagation, Growth and Metamorphosis of the Salmon, London: G. Routledge \& Company.

Knox, Robert. 1854b. "Fish Culture." The Illustrated London Magazine 2: 43-46.

Kohler, Robert. 2002. Landscapes \& Labscapes: Exploring the Lab-Field Border. Chicago: University of Chicago Press.

Kusch, Martin. 2007. “Towards a Political Philosophy of Risk: Experts and publics in Deliberative Democracy.” In Risk: Philosophical perspectives, edited by T. Lewens, 131-155. Routledge, New York.

"List of Members." 1866. The Transactions and Journal of the Proceedings of the Dumfriesshire \& Galloway Natural History and Antiquarian Society 2:11-12.

Lorimer, Jamie. 2007. “Nonhuman Charisma." Environment and Planning D: Society and Space 25(5):911-32.

Lynch, Michael, and John Law. 1988. "Lists, Field Guides, and the Descriptive Organization of Seeing: Birdwatching as an Exemplary Observational Activity.” Human Studies 11(2/3):271-303.

MacKenzie, Murdo. [1834] 1860. View of the Salmon Fishery of Scotland, 2nd edition, Edinburgh: William Blackwood \& Sons.

McMullin, Ernan. 1992. "Introduction: The Social Dimensions of Science." In The Social Dimensions of Science, edited by Ernan McMullin. Notre Dame IN: University of Notre Dame Press.

Merton, Robert K. 1968. “The Matthew Effect in Science.” Science 159(3810):56-63.

Milton, John S. 1836. "Observations and Experiments Proving the Parr or Branding to Be the Young of Salmon." Quarterly Journal of Agriculture 6(29):62-72.

M’Turk, Robert. "On Supplying Sheep with Food and Shelter." Prize Essay and Transactions of the Highland and Agricultural Society of Scotland (New Series), Vol. 8 (1843):631-51.

Munsche, P. B. 1981. “The Gamekeeper and English Rural Society, 1660-1830.” Journal of British Studies 20(2):82-105.

Murphy, Raymond. 1988. Social Closure: The Theory of Monopolization and Exclusion. Oxford: Clarendon Press.

"Obituary of John Shaw." 1867. Inverness Courier, 21 March p. 3.

Orland, Barbara. 2017. "The Invention of Artificial Fertilization in the Eighteenth and Nineteenth Century." History and Philosophy of the Life Sciences 39(11): https://doi.org/10.1007/s40656-017-0136-3.

Osborne, Harvey. 2007. “The Development of Salmon Angling in the Nineteenth Century." In Our Hunting Fathers: Field Sports in England after 1850, edited by Richard W Hoyle, 187-211. Lancaster: Carnegie.

Parkin, Frank. 1979. Marxism and Class Theory: A Bourgeois Critique. London: Tavistock Publications.

Parnell, Richard. 1838. "Natural and Economical History of the Fishes, Marine, Fluviatile, and Lacustrine, of the River District of the Firth of Forth." Memoirs of the Wernerian Natural History Society, for the Years 1831-1837, 7:161-520.

Parnell, Richard. 1840. "Account of a New Species of British Bream, and of an Undescribed Species of Skate." Transactions of the Royal Society of Edinburgh 14(1):146-57.

Pennant, Thomas. 1769. British Zoology. 3 Vols. London: Eliz. Adams for Benjamin White.

Podolny, Joel, and Freda Lynn. 2011. "Status." In The Oxford Handbook of Analytical Sociology, edited by Peter Hedström and Peter Bearman. Oxford: Oxford University Press.

Porter, Roy. 1978. "Gentlemen and Geology: The Emergence of a Scientific Career, 1660-1920." Historical Journal 21(4): 809-36.

Richards, Evelleen. 1989. “The 'Moral Anatomy' of Robert Knox: The Interplay between Biological and Social Thought in Victorian Scientific Naturalism.” Journal of the History of Biology 22(3):373-436.

Richards, Evelleen. 1994. "A Political Anatomy of Monsters, Hopeful and Otherwise: Teratogeny, Transcendentalism, and Evolutionary Theorizing." Isis 85(3):377-411.

Robertson, Iain Aitken. 1998. The Tay Salmon Fisheries since the Eighteenth Century, Glasgow: Cruinthe Press.

Ross, Sydney. 1962. "Scientist: The Story of a Word." Annals of Science 18(2):65-85.

Rudwick, Martin J.S. 1985. The Great Devonian Controversy: The Shaping of Scientific Knowledge among Gentlemanly Specialists. Chicago: University of Chicago Press.

Russel, Alexander. 1864. The Salmon. Edinburgh: Edmonston and Douglas.

Schneider, Daniel. 2000. "Local Knowledge, Environmental Politics, and the Founding of Ecology in the United States: Stephen Forbes and the "The Lake as a Microcosm" (1887)." Isis 91(4):681-705.

Scott, Walter. 1828. "Salmonia, or Days of Fly-Fishing." Quarterly Review 38(76):503-35.

Scrope, William. [1843] 1898. Days and Nights of Salmon Fishing in the Tweed, 2nd edition. London: Edward Arnold.

Second, Anne. 1994. "Corresponding Interests: Artisans and Gentlemen in Nineteenth-Century Natural History." British Journal of the History of Science 27(4):383-408.

Second, James A. 1991. "Edinburgh Lamarckians: Robert Jameson and the Robert E. Grant." Journal of the History of Biology 24(1):1-18.

Shapin, Steven. 1974. "The Audience for Science in Eighteenth Century Edinburgh.” History of Science 12(2): 95-121

Shapin, Steven. 1982. "History of Science and Its Sociological Reconstructions." History of Science 20(3):157-211.

Shapin, Steven. 1984. "Pump and Circumstance: Robert Boyle’s Literary Technology.” Social Studies of Science 14(4):481-520.

Shapin, Steven. 1991. "'A Scholar and a Gentleman': The Problematic Identity of the Scientific Practitioner in Early Modern England.” History of Science 29(3):279-327. 
Shapin, Steven. 1994. A Social History of Truth: Civility and Science in Seventeenth-Century England. Chicago: University of Chicago Press.

Shapin, Steven, and Barry Barnes. 1976. "Head and Hand: Rhetorical Resources in British Pedagogical Writing, 1770-1850." Oxford Review of Education 2(3):231-54.

Shaw, John. 1836. "An Account of Some Experiments and Observations on the Parr." The Edinburgh New Philosophical Journal 21(41):99-110.

Shaw, John. 1838. "Experiments on the Development and Growth of the Fry of the Salmon." The Edinburgh New Philosophical Journal 24(47):165-76.

Shaw, John. 1840a. "Account of Experimental Observations on the Development and Growth of Salmon-Fry." Transactions of the Royal Society of Edinburgh 14(2):547-66.

Shaw, John. 1840b. Experimental Observation on the Development and Growth of Salmon Fry Edinburgh: Adam \& Charles Black.

Sheail, J. 1998. “The Tweed Fisheries: An Historical Perspective.” The Science of the Total Environment 210/211(March): 469-82.

Stoddart, Thomas T. 1868. An Angler's Rambles and Angling Songs. Edinburgh: Edmonston and Douglas.

Walbaum, Johanne J. 1792. Petri Artedi sueci genera piscium. Radactis speciebus 242 and genera 52 Ichthyologiae pars III. Grypeswaldiae: Ant. Ferdin.

Weber, Max. 1978. Economy and Society: An Outline of Interpretive Sociology. Edited by Guenther Roth and Claus Wittich. Berkeley: University of California Press.

Westwood, Thomas. 1861. New Bibliotheca Piscatoria, London: The Field.

Wheeler, Alwyne. 2004. "Couch, Jonathan (1789-1870)." In Oxford Dictionary of National Biography, Oxford: Oxford University Press http://www.oxforddnb.com/view/article/6435 (last accessed September 20 2016).

Wilkins, Noel P. 1989. Ponds, Passes, and Parcs: Aquaculture in Victorian Ireland. Dublin: Glendale.

Willughby, Francis, and John Ray. 1686. Francisci Willughbeii Armig. De historia piscium libri quatuor, Oxford: Sheldonian Theatre.

Wilson, James. 1838. Introduction to the Natural History of Fishes. Edinburgh: Adam \& Charles Black.

Wilson, James. 1840. “Shaw on Salmon Fry.” Blackwood's Magazine 47(294):531-43.

Wilson, James. 1841. "On the Salmon Fry." In Report of the Tenth Meeting of the British Association of the Advancement of Science, 1840, 133-134. London: John Murray.

Wilson, James. 1842. "Ichthyology." Encyclopedia Britannica. 7th ed. vol. 2: 151-240. Edinburgh: Adam and Black.

Wilson, James. 1843. "Natural History of Salmon and Sea Trout." Blackwood's Magazine 53 (331):640-650.

Yarrell, William. 1835. A History of British Fishes. 1st edition, 2 vols. London: John Van Voorst.

Yarrell, William. 1839a. On the Growth of the Salmon in Fresh Water, London: John Van Voorst.

Yarrell, William. 1839b. Supplement to the History of British Fishes, London: John Van Voorst.

Yarrell, William. 1841. A History of British Fishes. 2nd edition, 2 vols. London: John Van Voorst.

Young, Andrew. 1844. "On the Growth of Grilse and Salmon.” Transactions of the Royal Society of Edinburgh 15 (3):343-438.

Young, Andrew. 1848. The Natural History and Habits of the Salmon. Wick: Peter Reid.

Reuben Message is a sociologist of science, technology and animals in society. He is a researcher in the School of Geography and the Environment, University of Oxford and holds a PhD from the London School of Economics. His research deals mainly with the sociological history of the development of aquaculture and angling technologies, and controversies associated with welfare of animals (especially fish). He is currently a part of the Animal Research Nexus project which explores the changing constitutions of science, health and welfare in the UK.

Cite this article: Message, Reuben. 2019. "The Disadvantages of a Defective Education”: Identity, Experiment and Persuasion in the Natural History of the Salmon and Parr Controversy, c. 1825-1850, Science in Context 32:261-284. doi:10.1017/ S0269889719000255 